\title{
FEATURES OF PHYSICAL DEVELOPMENT, PHYSICAL PREPAREDNESS AND FUNCTIONAL STATE OF BOYS AND GIRLS - STUDENTS OF POLISH HIGHER EDUCATIONAL ESTABLISHMENTS
}

\author{
Prusik Krzysztof $^{1}$, Prusik Katarzyna ${ }^{1}$, Kozina Zh.L. ${ }^{2}$, Iermakov S.S. ${ }^{2}$
}

Academy of physical education and sports ${ }^{2}$, Gdansk $^{1}$, Poland

G.S. Skovsroda Kharkov national pedagogical university ${ }^{2}$

\begin{abstract}
The features of level and structure of indexes of physical development, physical preparedness and functional state of students are considered. In research 50 took part students of Higher School of Sciences about health from Bydgoshch (14 boys and 36 girls, age 18-29 years). Reliable distinctions are exposed in physical preparedness and functional state of boys and girls on the indexes of force. Indexes of psychophysiological possibilities, frequencies of heart-throbs in a state of rest, the index of Ruf'e have no reliable distinctions at boys and girls. It is shown that power capabilities have the most value in complex preparedness of boys. Functional and psychophysiological possibilities have the most value in complex preparedness of girls. The factor structure of preparedness of girls is differ by greater complication as compared to boys. On the level of physical preparedness and functional state of girls in a greater degree of anthropometric information have influence as compared to boys. Power capabilities for girls occupy middle position in the general structure of preparedness, while for boys' power capabilities occupy leading position. It is shown that on employments on physical education of boys it is necessary to do an accent on development of force, while for girls - on development of endurance (functional possibilities) and in a greater degree as compared to boys it is necessary to take into account psychophysiological possibilities.
\end{abstract}

Keywords: students, functional, psychophysiological, physical, preparedness, boys, girls, speed of reaction, force.

\section{Introduction.}

At present an objective study of gender differences in various aspects of functional status, physical preparation and psychophysiological features has particular relevance [7,8]. This problem has its roots in the distant past, because people are always worried about the problem of the features of male and female body, connected with various biological and social roles of men and women [8]. At the present stage, when there is an obliteration of differences in the social sphere of men and women, this issue is of particular relevance. The greatest expression of the necessity to conduct such research is in the field of physical education, particularly in the physical education of students, because physical education is most closely associated with the biological preconditions of psychomotor development, and adolescence is the final phenotypic consolidation of genotypic sex differences $[5,6,8,9,10-20]$.

There are many different points of view according to gender differences in the modern literature.

As noted E.P. Ilyin [8], in time of A.S. Pushkin and M.Yu. Lermontov a strong man and a woman (or girl) "poor health" were standards in high society. Some of the girls to correspond to such standard even drank vinegar causing both pallor and stomach illness. K. Marx, in response to daughters' questionnaire, also did not escape the effects of these stereotypes, saying that the main sign of the dignity of a man is the power, and woman - weakness.

However, as the author notes [8], now women sporting type with a slim figure and developed psychomotor qualities are in vogue. To contribute such ideal promotes physical exercise.

However, the E.P. Ilyin critically illuminates feminist points of view according to men and women equal opportunities in various fields on the basis of factual scientific researches.

In a review of studies [8] devoted to this problem, E.P. Ilyin points out that scientists of our country are strongly disagree with those representatives of Western science who seek to prove the equal opportunities of men and women in society. I.S. Kon (1981) emphasizes the importance of taking into account gender differences in the study of identity formation. Theoretical underestimation of sex, says I.S. Kon, almost turns that traditionally masculine characteristics and patterns of behavior unwittingly accepted and paid for the universal, which distorts the real picture of the gender-specific.

The same notes E.P. Korablina (1998), V.D. Yeremeeva and T.P. Hrizman (2001), who emphasize the importance of sex differences in child rearing.

R. Davis and A. Buchwald (R. Davis, A. Buchwald, 1957) point out that the same stimulus can cause men and women of different physiological changes.

E.P. Ilyin notes that the most clearly differences between men and women are found on psychomotor abilities in spatial imagination and mathematical abilities (in favor of men), on verbal abilities (in favor of women). One notes that the existing differences in the intellectual sphere are very insignificant and often do not exceed 5-10\%, and in 90\% distribution of male and female samples coincide (E. Maccoby, C. Jacklin, 1974; Pleck, 1978; D. Halpern, 1986 ; D. Ruble, 1988; J. Hyde, 1991).

A number of researchers $[6,7,8,10]$ indicate that the overemphasis of sex differences, harsh contrasting of masculine and feminine, traditionally carried out for a long time, has its drawbacks. According to I.S. Kon (1981), there was long dispute as to whether a more desirable polarization of masculine and feminine with a maximum matching of individual characteristics with the appropriate cultural stereotype (strong, tough, energetic man, weak, soft, passive,

(c) Prusik Krzysztof, Prusik Katarzyna, Kozina Zh.L., lermakov S.S., 2012

doi: 10.6084/m9.figshare.96415 
female) or, alternatively, their overcome and combination in one person (strong, but also soft and gentle man, but at the same time an independent woman). And at higher levels of culture and philosophical reflection preference is usually given to the second model that promises greater understanding of sex, while in the first case their relationships are thought to be hierarchical based on domination and subordination [8].

Thus, the issue of gender differences remains relevant, as related to changing social conditions combined with relatively constant biological assumptions.

The work was performed in accordance with the Consolidated Plan of Research of the Ministry of Education and Science, Youth and Sports of Ukraine on theme 2.4 "Theoretical and methodological foundations of personalization of educational-training process of athletes in team sports" and on theme 91 "Theoretical and methodological basis of personalization in physical education and sports" (number of state registration 0112U002001).

Purpose, tasks of the paper, material and methods.

The purpose of a study - to determine the features of the level and structure of indexes of physical development, physical training and functional status of boys and girls - students of higher educational establishment.

Methods of research. In the paper is used anthropometric methods of research from which to analyze Ketle Index was selected as the most informative indicator of the ratio of length and weight, and the length of the forearm for subsequent determination of the torque value in flexion forearm; from the indexes of physical training was determined the hand and forearm flexor force with a dynamometer, indexes of flexibility of the spine; from the indexes of functional status determined Ruf'e index and indicators of ortho tests and physiological indicators: simple reaction time on light, simple reaction time on sound, choice reaction time, an estimation of precision and speed of producing the desired motor movements [1-4], and indexes of Romberg test and orthostatic test.

The study involved 50 students of Higher School of Health Science from Bydgoshch, including 14 boys and 36 girls, middle age 24,00 $\pm 5,39$ (girls) and 26,64 \pm 6,16 (boys). The studies were conducted in May 2012 in kinesiology exercises. The choice of research is grounded on the fact that Poland has a central position not only from the point of view of geography, but also from the point of view of standard of living, life expectancy, health status among European countries. Suppose that the analysis of parameters of physical development, physical training and functional status of the Polish students reflects average physical development, physical training and functional status of students in Europe.

Results of the research.

According to the study, significant differences in the level of physical training and functional status between boys and girls identified in terms of power capacity $(\mathrm{p}<0,001, \mathrm{p}<0,05)$ (Table 1). For other studied parameters revealed a tendency for differences without statistical difference.

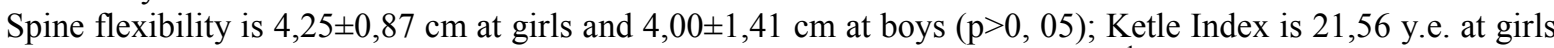
and 21,92 y.e. at boys $(\mathrm{p}>0,05)$; heart rate in a state of rest is $72,00 \pm 6,16$ rate per min $^{-1}$ at girls and $74,29 \pm 7,27$ rate per $\min ^{-1}$ at boys $(\mathrm{p}>0,05)$ (Table 1$)$.

There were no significant differences between the indices of heart rate (HR) of boys and girls immediately after physical load. This index is equal to 126,44 rate per $\min ^{-1}$ at girls and 132, 71 rates per $\min ^{-1}$ at boys ( $p>0,05$ ) (Table 1), though in such case one can consider an existence of tendency to differences. Also there are no significant differences between boys and girls in terms of heart rate in the first minute recovery $\left(81,67 \pm 12,69\right.$ rates per min $^{-1}$ at girls and $86,57 \pm 15,58$ rates per $\min ^{-1}$ at boys) ( $\left.>00,05\right)$; according to Ruf'e index $(8,01 \pm 3,39$ y.e. at girls and 9 , $36 \pm 4,5$ y.e. at boys) ( $>0,05)$; according to indicators of ortho tests: HR lying is $69,25 \pm 13,6369$ rates per min $^{-1}$ at girls and $71,86 \pm 10,95$ rates per $\min ^{-1}$ at boys $(p>0,05)$; HR standing is $71,5 \pm 15,56$ rates per min ${ }^{-1}$ at girls and 72 , $86 \pm 16,88$ rates per $\min ^{-1}$ at boys $(p>0,05)$; change of HR crossing from the state of lying into the state of standing is not exceeding 5 rates per $\min ^{-1}$ both at girls and boys that may explain the increased emotional response of testee during the test; the differences in the change in heart rate in orthostatic between boys and girls as not significant ( $p>0,05$ ) (Table 1).

In indexes of psycho-physiological capabilities also found no significant differences between boys and girls: accuracy rate of motion along a given path was $0,22 \pm 0,02$ y.e. at girls and $0,26 \pm 0,023$ y.e. at boys ( $>00,05)$; the speed of the brush to the desired path was like the boys and girls $0,08 \mathrm{~m} \mathrm{sec}^{-1}(\mathrm{p}>0,05)$; simple reaction time on the sound was found to be $0,36 \pm 0,06 \mathrm{sec}$ at girls and $0,35 \pm 0,06 \mathrm{sec}$ at boys $(\mathrm{p}>0,05)$ (Table 1$)$. It should be noted a trend to a higher rate of reaction of choice for girls compared with boys: 0, 91 $\pm 1,3 \mathrm{sec}$ at girls and 1, 27 $\pm 2,28 \mathrm{sec}$ at boys $(\mathrm{p}>0,05)$ (Table 1).

Significant differences among the measured parameters in this study were found in the right hand dynamometry, dynamometry of left hand, forearm flexor force, moment of force, as well as the length of the forearm, ie in indicators related to the manifestation of strength and anthropometric data. Dynamometry of left hand is $32,81 \pm 9,27$ $\mathrm{kg}$ at girls and $44,49 \pm 12,77 \mathrm{~kg}$ at boys $(\mathrm{p}<0,05)$; right hand dynamometry is $31,22 \pm 7,97 \mathrm{~kg}$ at girls and $43,69 \pm 12$, $43 \mathrm{~kg}$ at boys $(\mathrm{p}<0,05)$ (Table 1). Forearm flexor strength at girls is equal to $8,63 \pm 3,26 \mathrm{~kg}$, at boys $-10,79 \pm 4,08 \mathrm{~kg}$ $(\mathrm{p}<0,05)$, moment of force during arm flexion was $2,21 \pm 0,89 \mathrm{~kg} \cdot \mathrm{m}^{2} \cdot \mathrm{sec}^{-2}$ at girls and $2,91 \pm 1,21 \mathrm{~kg} \cdot \mathrm{m}^{2} \cdot \mathrm{sec}^{-2}$ at boys $(\mathrm{p}<0,05)$ (Table 1). 
Table 1

Indexes of physical development, physical preparation and functional status of boys and girls

\begin{tabular}{|c|c|c|c|c|c|}
\hline Indexes & Groups & $\bar{x}$ & $\mathrm{~S}$ & $\mathrm{t}$ & $\mathrm{p}$ \\
\hline \multirow{2}{*}{ Flexibility of the spine, $\mathrm{cm}$} & girls & 4.25 & 0.87 & \multirow{2}{*}{0.76} & \multirow{2}{*}{0.45} \\
\hline & boys & 4.00 & 1.41 & & \\
\hline \multirow{2}{*}{ Ketle index, y.e } & girls & 21.56 & 2.25 & \multirow{2}{*}{-0.55} & \multirow{2}{*}{0.58} \\
\hline & boys & 21.92 & 1.32 & & \\
\hline \multirow{2}{*}{ Age } & girls & 24.00 & 5.39 & \multirow{2}{*}{-1.43} & \multirow{2}{*}{0.16} \\
\hline & boys & 26.64 & 7.04 & & \\
\hline \multirow{2}{*}{ Heart rate at rest, rates per $\min ^{-1}$} & girls & 72.00 & 6.16 & \multirow{2}{*}{-1.12} & \multirow{2}{*}{0.27} \\
\hline & boys & 74.29 & 7.27 & & \\
\hline \multirow{2}{*}{$\begin{array}{l}\text { Heart rate directly after physical } \\
\text { loading, rates per } \min ^{-1}\end{array}$} & girls & 126.44 & 21.23 & \multirow{2}{*}{-0.86} & \multirow{2}{*}{0.39} \\
\hline & boys & 132.71 & 27.57 & & \\
\hline \multirow{2}{*}{$\begin{array}{l}\text { Heart rate in a first minute of renewal, } \\
\qquad \text { per } \min ^{-1}\end{array}$} & girls & 81.67 & 12.69 & \multirow{2}{*}{-1.15} & \multirow{2}{*}{0.26} \\
\hline & boys & 86.57 & 15.58 & & \\
\hline \multirow{2}{*}{ Ruf'e index, y.e. } & girls & 8.01 & 3.39 & \multirow{2}{*}{-1.15} & \multirow{2}{*}{0.26} \\
\hline & boys & 9.36 & 4.50 & & \\
\hline \multirow{2}{*}{ Romberg test, c } & girls & 14.81 & 9.11 & \multirow{2}{*}{0.06} & \multirow{2}{*}{0.95} \\
\hline & boys & 14.64 & 3.67 & & \\
\hline \multirow{2}{*}{$\begin{array}{l}\text { The accuracy of the arm to the desired } \\
\text { path, y.e }\end{array}$} & girls & 0.22 & 0.02 & -061 & 055 \\
\hline & boys & 0.26 & 0.023 & -0.01 & 0.55 \\
\hline The speed of the arm to the desired & girls & 0.08 & 0.03 & 003 & 008 \\
\hline path, $\mathrm{m} \cdot \sec ^{-1}$ & boys & 0.08 & 0.04 & 0.03 & 0.98 \\
\hline Ieft wrict dynamometry $\mathrm{ko}$ & girls & 32.81 & 9.27 & -350 & 000 \\
\hline Left wrist dynamometry, $\mathrm{kg}$ & boys & 44.49 & 12.77 & -3.59 & 0.00 \\
\hline & girls & 31.22 & 7.97 & -4.22 & 0.00 \\
\hline Right wrist dynamometry, kg & boys & 43.69 & 12.43 & -4.22 & 0.00 \\
\hline & girls & 0.26 & 0.01 & -228 & 003 \\
\hline Forearm length, $\mathrm{m}$ & boys & 0.27 & 0.02 & -2.28 & 0.03 \\
\hline & girls & 8.63 & 3.26 & -196 & 006 \\
\hline The strength of the forearm flexor, kg & boys & 10.79 & 4.08 & & \\
\hline Moment of force of arm flexion, & girls & 2.21 & 0.89 & -224 & 003 \\
\hline $\mathrm{kg} \cdot \mathrm{m}^{2} \cdot \mathrm{sec}^{-2}$ & boys & 2.91 & 1.21 & -2.24 & 0.03 \\
\hline Simnle reaction time on a sound sec & girls & 0.36 & 0.06 & 050 & 062 \\
\hline simple reaction time on a sound, sec & boys & 0.35 & 0.06 & 0.50 & 0.62 \\
\hline Choice reaction time sec & girls & 0.91 & 1.30 & -107 & 006 \\
\hline Choice reaction time, sec & boys & 1.27 & 2.28 & -1.97 & 0.06 \\
\hline Simple reaction time on lioht sec & girls & 1.24 & 1.28 & -011 & 092 \\
\hline & boys & 1.28 & 1.36 & & 0.92 \\
\hline Heart rate lying rates ner $\mathrm{min}^{-1}$ & girls & 69.25 & 13.63 & $=064$ & 0.53 \\
\hline & boys & 71.86 & 10.95 & -0.04 & 0.55 \\
\hline Heart rate standing rates ner $\mathrm{min}^{-1}$ & girls & 71.50 & 15.56 & $=027$ & 070 \\
\hline & boys & 72.86 & 16.88 & -0.21 & 0.19 \\
\hline Heart rate standing - Heart rate lying, & girls & 2.25 & 10.48 & 038 & 071 \\
\hline rates per $\min ^{-1}$ & boys & 1.00 & 10.40 & 0.38 & 0.11 \\
\hline
\end{tabular}

Thus, significant differences in the physical preparation and functional status of men and women were found only according to the indexes of power. Psychophysiological indicators of opportunities for boys and girls do not have significant differences, as well as indicators of heart rate at rest, immediately after the physical loading, the first minute of recovery and index of Ruf'e index, that partly confirms the findings of other authors [8] on minor sex differences in psychophysiological features and significant gender differences in the power development.

To analyze the structure of physical preparation, functional status and psychophysiological features of students was conducted a factor analysis method of principal components. In this study, factor analysis was used to determine the relationships between variables, classification of variables and reduce the number of variables to describe the data. It was determined factor structure of comprehensive training of boys, girls and all students surveyed in general. Factor analysis revealed additional features of the integrated training of boys and girls. 
In the structure of boys preparation were allocated four factors.

The first factor consisted of the following test scores: the length of the forearm $(\mathrm{r}=0,82)$, simple reaction time on sound $(\mathrm{r}=-0,81)$, moment of force during arm flexion $(\mathrm{r}=0,78)$, Ketle index $(\mathrm{r}=-0,77)$, forearm flexor strength $(\mathrm{r}=0,70)$, right wrist dynamometry $(\mathrm{r}=0,66)$, left wrist dynamometry $(\mathrm{r}=0,64)$ (Table 2$)$.

Based on analysis of test scores included in the first factor, it was defined as "Power abilities".

The second factor consisted the following indexes as Ruf'e index $(\mathrm{r}=0,82)$, heart rate on a first minute of renewal $(\mathrm{r}=0,90)$, heart rate directly after physical loading $(\mathrm{r}=0,84)$, heart rate in state of rest $(\mathrm{r}=0,79)($ Table 2$)$. Based on analysis of test scores included in the first factor, it was defined as "Functionality".

Table 2

Factor structure of complex preparation of boys

\begin{tabular}{|c|c|c|c|c|}
\hline \multirow{4}{*}{ Indexes } & \multicolumn{4}{|c|}{ Factors } \\
\hline & 1 & 2 & 3 & 4 \\
\hline & $27.73 \%$ & $21.28 \%$ & $17.55 \%$ & $9.23 \%$ \\
\hline & Power abilities & $\begin{array}{l}\text { Functional } \\
\text { opportunities }\end{array}$ & $\begin{array}{l}\text { Psychophysiologic } \\
\text { al opportunities }\end{array}$ & $\begin{array}{l}\text { Coordinational } \\
\text { abilities }\end{array}$ \\
\hline Forearm length, $\mathrm{m}$ & 0.82 & & & \\
\hline $\begin{array}{l}\text { Time of simple reaction on a sound, } \\
\text { sec }\end{array}$ & -0.81 & & & \\
\hline $\begin{array}{l}\text { Moment of force during the forearm } \\
\text { flexor, } \mathrm{kg} \cdot \mathrm{m}^{2} \cdot \mathrm{sec}^{-2}\end{array}$ & 0.78 & -0.515 & & \\
\hline Ketle index, y.e & -0.77 & & & \\
\hline $\begin{array}{l}\text { The strength of the forearm flexor, } \\
\qquad \mathrm{kg}\end{array}$ & 0.70 & -0.54 & & \\
\hline Right wrist dynamometry, $\mathrm{kg}$ & 0.66 & -0.42 & & \\
\hline Left wrist dynamometry, $\mathrm{kg}$ & 0.64 & & & \\
\hline Ruf'e index, y.e. & & 0.95 & & \\
\hline $\begin{array}{l}\text { Heart rate after physical loading, } \\
\text { rates per } \min ^{-1}\end{array}$ & & 0.90 & & \\
\hline $\begin{array}{l}\text { Heart rate directly after physical } \\
\text { loading, rates per } \min ^{-1}\end{array}$ & & 0.84 & & \\
\hline $\begin{array}{l}\text { Heart rate in a state of rest, rates per } \\
\min ^{-1}\end{array}$ & & 0.79 & -0.42 & \\
\hline Heart rate standing, rates per $\min ^{-1}$ & & & 0.96 & \\
\hline $\begin{array}{c}\text { Heart rate standing - Heart rate lying, } \\
\text { rates per } \min ^{-1}\end{array}$ & & & 0.86 & \\
\hline Choice reaction time, sec & 0.48 & & 0.80 & \\
\hline Simple reaction time on light, sec & & & -0.75 & \\
\hline Heart rate lying, rates per $\min ^{-1}$ & 0.42 & & 0.65 & \\
\hline $\begin{array}{l}\text { The speed of the arm to the desired } \\
\text { path, } \mathrm{m}^{\cdot} \mathrm{sec}^{-1}\end{array}$ & & & & -0.80 \\
\hline $\begin{array}{l}\text { The accuracy of the arm to the } \\
\text { desired path, y.e }\end{array}$ & & & & 0.77 \\
\hline Flexibility of the spine, $\mathrm{cm}$ & & -0.41 & & 0.74 \\
\hline
\end{tabular}

The third factor consisted the following indexes as heart rate standing $(\mathrm{r}=0,96)$, difference between heart rate in state of standing and state of lying $(r=0,86)$, choice reaction time $(r=0,80)$, simple reaction time on light $(r=-0,75)$, heart rate in state of lying $(\mathrm{r}=0,65)$. As far as the third factor consist indexes of speed reaction and indexes of ortho tests that reflex vegeto vascular regulation, third factor was determined as "Psychophysical opportunities" (Table 2).

The fourth factor include speed indexes and accuracy of speed of arm to the desired path $(\mathrm{r}=-0,80 ; 0,77)$ and flexibility of the spine $(\mathrm{r}=0,74)$. On the basis of the indicators included in the fourth factor, he was named a "Coordinating capacity" (Table 2).

Thus, in the complex training of youths the most importance have power capacities, than followed functionality, physiological capacities and coordination abilities.

Table 3 shows the characteristics of complex testing factors of girls. 
The first factor includes the following indexes of testing: Ruf'e index $(\mathrm{r}=0,98)$, heart rate on a first minute of renewal $(\mathrm{r}=0,80)$, heart rate directly after physical loading $(\mathrm{r}=0,91)$, heart rate in state of rest $(\mathrm{r}=0$, 63), Ketle index $(\mathrm{r}=0,61)$ (Table 3). Based on analysis of test scores included in the first factor, it was defined as "Functional opportunities".

The second factor includes the following indexes: heart rate in state of lying $(\mathrm{r}=0,88)$, choice reaction time $(\mathrm{r}=0,85)$, heart rate in state of standing $(\mathrm{r}=0,84)$. Based on analysis of test scores included in the second factor, it was defined as "Psychophysiological opportunities".

The third factor includes such indexes as right wrist dynamometry $(\mathrm{r}=0,86)$, the strength of the forearm flexor $(\mathrm{r}=0,80)$, moment of force during the forearm flexor $(\mathrm{r}=0,76)$, left wrist dynamometry $(\mathrm{r}=0,73)$. In generalizing these indicators third factor was named "Power abilities" (Table 3 ).

The fourth factor include indexes of simple reaction time on light $(r=0,78)$ and girls' ages $(r=-0,44)$. These data suggest that older students have worse simple reaction time, so the fourth factor was named "Age features" (Table $3)$.

Table 3

Factor structure of complex preparation of girls

\begin{tabular}{|c|c|c|c|c|c|c|}
\hline \multirow{4}{*}{ Indexes } & \multicolumn{6}{|c|}{ Factors } \\
\hline & 1 & 2 & 3 & 4 & 5 & 6 \\
\hline & $20.66 \%$ & $15.78 \%$ & $13.36 \%$ & $7.69 \%$ & $7.02 \%$ & $6.07 \%$ \\
\hline & $\begin{array}{l}\text { Functional } \\
\text { opportunities }\end{array}$ & $\begin{array}{c}\text { Psychophysio } \\
\text { logical } \\
\text { opportunities }\end{array}$ & $\begin{array}{l}\text { Power } \\
\text { abilities }\end{array}$ & Age abilities & $\begin{array}{l}\text { Anthropomet } \\
\text { ic data }\end{array}$ & $\begin{array}{c}\text { Coordinationa } \\
1 \text { abilities }\end{array}$ \\
\hline Ruf'e index, y.e. & 0.98 & & & & & \\
\hline $\begin{array}{c}\text { Heart rate directly after } \\
\text { physical loading, rates per } \min ^{-1}\end{array}$ & 0.91 & & & & & \\
\hline $\begin{array}{l}\text { Heart rate in a first minute of } \\
\text { renewal, per } \min ^{-1}\end{array}$ & 0.80 & & & & & \\
\hline $\begin{array}{l}\text { Heart rate in a state of rest, } \\
\text { rates per } \mathrm{min}^{-1}\end{array}$ & 0.63 & & & 0.47 & & \\
\hline Ketle index, y.e & 0.61 & & & & & \\
\hline Heart rate lying, rates per $\min ^{-1}$ & & 0.88 & & & & \\
\hline Choice reaction time, sec & & 0.85 & & & & \\
\hline $\begin{array}{l}\text { Heart rate standing, rates per } \\
\min ^{-1}\end{array}$ & & 0.84 & & & & \\
\hline Right wrist dynamometry, kg & & & 0.86 & & & \\
\hline $\begin{array}{l}\text { The strength of the forearm } \\
\text { flexor, } \mathrm{kg}\end{array}$ & & & 0.80 & & & \\
\hline $\begin{array}{l}\text { Moment of force during the } \\
\text { forearm flexor, } \mathrm{kg} \cdot \mathrm{m}^{2} \cdot \mathrm{sec}^{-2}\end{array}$ & & & 0.76 & 0.44 & & \\
\hline Left wrist dynamometry, $\mathrm{kg}$ & & & 0.73 & & & \\
\hline $\begin{array}{c}\text { Time of simple reaction on a } \\
\text { light, } \mathrm{c}\end{array}$ & & & & 0.78 & & \\
\hline Age & 0.43 & & & -0.44 & & \\
\hline $\begin{array}{l}\text { Heart rate standing - Heart rate } \\
\text { lying, rates per } \min ^{-1}\end{array}$ & & & & & 0.89 & \\
\hline Forearm length, $\mathrm{m}$ & & & & 0.44 & 0.45 & \\
\hline Romberg test, sec & & & & & & 0.78 \\
\hline $\begin{array}{l}\text { The speed of the arm to the } \\
\text { desired path, } \mathrm{m} \cdot \mathrm{sec}^{-1}\end{array}$ & & & & & & 0.72 \\
\hline
\end{tabular}

The fifth factor include indexes of ortho tests (differences between heart rate in state of standing and heart rate in lying) $(\mathrm{r}=0,89)$ and forearm length of $(\mathrm{r}=0,45)$. As length of forearm is connected to body length, increase of heart rate crossing from the state of lying to the state of standing is more expressed at people with more length of body, the forth factor was named "Anthropometric data" (Table 3).

The sixth factor include indexes of Romberg tests $(\mathrm{r}=0,78)$ and velocity of bone motion to the desired path $(\mathrm{r}=0,72)$, on the basis of which sixth factor was defined as "Coordinational abilities" (табл. 3).

Thus, in the complex training of girls the most importance have functional and physiological features, then power abilities, age features, anthropometric data and coordination abilities. In general, the factor structure of 
preparedness of girls is more complex than at boys. The level of physical preparation and functional status of women more influence age-specific anthropometric data and compared with boys. The power capacities of girls occupy a central position in the overall training, while at the young men power capacities occupy a leading position. The issues identified features in the structure of the complex preparedness of boys and girls in physical education of boys should be focuses on the development of strength, while the girls - the development of endurance (functionality) and to a greater extent than boys to consider psychophysiological opportunities.

Similarly, an analysis of the integrated training of all students, boys and girls was conducted. It was revealed that the overall structure of the preparedness of students is similar to the structure of youth preparation: the first factor $(20,82 \%)$ - "Power abilities", the second factor $(16,11 \%)$ - "Functional opportunities", the third factor (13, 87\%) "Psychophysiological opportunities", the fourth factor $(8,49 \%)$ - "Age abilities", the fifth factor (7, 00\%) "Coordinational abilities" (Table 4).

Table 4

Comparative characteristics of the factor structure of complex training of boys, girls and the group as a whole

\begin{tabular}{|c|c|c|c|}
\hline № factor & $\begin{array}{c}\text { General factor structure of students' } \\
\text { preparation }\end{array}$ & $\begin{array}{c}\text { Factor structure of boys' } \\
\text { preparation }\end{array}$ & $\begin{array}{c}\text { Factor structure of girls' } \\
\text { preparation }\end{array}$ \\
\hline 1 & Power abilities, $20.82 \%$ & Power abilities, $27.73 \%$ & $\begin{array}{c}\text { Functional opportunities, } \\
20.66 \%\end{array}$ \\
\hline 2 & Functional opportunities, $16.11 \%$ & $\begin{array}{l}\text { Functional opportunities, } \\
21.28 \%\end{array}$ & $\begin{array}{c}\text { Psychophysiological } \\
\text { opportunities, } 15.78 \%\end{array}$ \\
\hline 3 & $\begin{array}{c}\text { Psychophysiological opportunities, } \\
13.87 \%\end{array}$ & $\begin{array}{c}\text { Psychophysiological } \\
\text { opportunities, } 17.55 \%\end{array}$ & Power abilities, $13.36 \%$ \\
\hline 4 & Age abilities, $8.49 \%$, & $\begin{array}{c}\text { Coordinational abilities, } \\
9.23 \%\end{array}$ & Age abilities, $7.69 \%$ \\
\hline 5 & Coordinational abilities, $7.00 \%$ & & $\begin{array}{c}\text { Anthropometric data, } \\
7.02 \%\end{array}$ \\
\hline 6 & & & $\begin{array}{c}\text { Coordinational abilities, } \\
6.07 \% \\
\end{array}$ \\
\hline Sum & $66.29 \%$ & $75.81 \%$ & $70.59 \%$ \\
\hline
\end{tabular}

Obtained results show that the current process of training in high school involves a high level of physical training, which linked to the general level of health, the development of physical qualities. On physical education classes at high school should be considered sexual characteristics of the students. Physical education of girls and boys should be tailored to the main factors determining the complex structure of their training.

Summary.

1. There were significant differences in the physical training and functional status of men and women in terms of power. Psychophysiological indicators of capacity, heart rate at rest, immediately after the physical loading, on the first minute of recovery and rate index Ruf'e at boys and girls do not have significant differences.

2. It is shown that in the complex training of boys the most importance have power capacity, followed by functionality, physiological capacity and coordination abilities.

3. It is shown that in the complex training of the girls the most importance have functional and physiological features, then - power abilities, age characteristics, anthropometric data and coordination abilities. In general, the factor structure of preparedness of girls is more complex than at boys. The level of physical preparation and functional status of women more influence age-specific anthropometric data and compared with boys. The power capacity of girls occupy a central position in the overall preparation structure, while at boys power capacity can occupy a leading position.

4. It is shown that, in connection with the identified features in the structure of the complex preparedness of boys and girls in the classes of physical education of boys should focus on the development of strength, while at girls development of endurance (functionality) and to a greater degree than boys should take into account physiological features.

In the future, further research is planned to study the individual typological features of the Polish students. 


\section{References:}

1 Ashanin V.S., Filenko L.V. Fiziceskoe vospitanie studentov tvorceskih special'nostej [Physical Education of the Students of Creative Profession], 2008, vol.3, pp. 3-8.

2 Ashanin V.S., Golosov P.P., Gorbatenko Iu.I. Fiziceskoe vospitanie studentov [Physical Education of Students], 2010, vol.2, pp. 11-13.

3 Ashanin V.S., Nesterenko N.S. Fiziceskoe vospitanie studentov tvorceskih special'nostej [Physical Education of the Students of Creative Profession], 2008, vol.2, pp. 84-90.

4 Ashanin V.S. Slobozhans'kij naukovo-sportivnij visnik [Slobozhansky scientific and sport bulletin], 2004, vol.7, pp. 239-243.

5 Bondarev D.V., Gal'chinskij V.A. Fiziceskoe vospitanie studentov tvorceskih special'nostej [Physical Education of the Students of Creative Profession], 2008, vol.1, pp. 59-64.

6 Dubrovskij V. I. Valeologiia. Zdorovyj obraz zhizni [Valeology. Healthy lifestyle], Retorika-A, 2001,560 p.

7 Zajcev V.P., Kramskoj S.I., Manucharian S.V., Poliakova M.A., Evsiutina V.B. Fiziceskoe vospitanie studentov tvorceskih special'nostej [Physical Education of the Students of Creative Profession], 2009, vol.3, pp. 77-82.

8 Il'in E.P. Differencial'naia psikhofiziologiia muzhchiny $i$ zhenshchiny [Differential psychophysiology of man and woman], Sankt Petersburg, SSU Publ., 2003, 366 p.

9 Kozina Zh.L., Barybina L.N., Grin' L.V. Fiziceskoe vospitanie studentov [Physical Education of Students], 2010, vol.5, pp.30-35.

10 Platonov V.N. Sistema podgotovki sportsmenov $v$ olimpijskom sporte [The system of preparation of sportsmen in Olympic sport], Kiev, Olympic Literature, 2004, T.4, 607 p.

11 Agnieszka Woronkowicz, Barbara Anna Cichocka, Malgorzata Kowal, Lukasz Kryst, Jan Sobiecki. Physical development of girls from Krakow in the aspect of socioeconomical changes in Poland (1938-2010). American Journal of Human Biology. 2012, vol.24, Issue 5, pp. 626-632. doi:10.1002/ajhb.22283

12 Fetro J.V. Health literate youth: evolving challenges for health educators. American Journal of Health Education, 2010, vol. 41, no. 5, pp. 258-264.

13 Marks R. Healthy schools and colleges: what works, what is needed, and why? Health Education, 2010, vol.110, no. 4, pp. 421-426.

14 Marta Anczewska, Katarzyna Charzynska. Educational assessment of pupils in Poland. SA-eDUC JOURNAL, 2012, vol.9(1), pp. 11-19.

15 Martin P., McCullagh J. Physical education and outdoor education: complementary but discrete disciplines. Asia-Pacific Journal of Health, Sport and Physical Education, 2011, vol. 2, no. 1, pp. 67-78.

16 McKenzie T., Lounsbury M. School Physical Education: The pill not taken. American Journal of Lifestyle Medicine, 2009, vol. 3, no. 3, pp. 219-225.

17 Nutbeam D. The evolving concept of health literacy. Social Science and Medicine, 2008, vol. 67, pp. $272-278$.

18 Renson R. Messages from the future: significance of sport and exercise in the third millennium. European Journal of Sport Science, 2001, vol.1, no. 1, pp. 1-17.

19 Resiak Malgorzata, Niedzielska Aleksandra. The Level of Physical Development and Physical Fitness in 6-7Year-Old Children from School and Pre-School Institutions in Gdansk. Baltic Journal of Health and Physical Activity. 2009, vol.3, Issue 4, pp. 286-292,

20 Tinning R.=Aliens in the gym: Considering the learner in physical education, Healthy Lifestyles Journal, 2008, vol. 54 , no. 2 , pp. 13-19. 
Information about the authors:

Prusik Krzysztof: prusik@hot.pl; Academy of Physical Education and Sports; ul. Wiejska 1, 80-336 Gdansk, Poland.

Prusik Katarzyna: prusik@hot.pl; Academy of Physical Education and Sports; ul. Wiejska 1, 80-336 Gdansk, Poland.

Kozina Zh.L.: zhanneta.kozina@gmail.com; Kharkov National Pedagogical University; Artema str. 29, Kharkov, 61002, Ukraine.

Iermakov S.S.: sportart@gmail.com; Kharkov National Pedagogical University; Artema str. 29, Kharkov, 61002, Ukraine.

Cite this article as: Prusik Krzysztof, Prusik Katarzyna, Kozina Zh.L., Iermakov S.S. Features of physical development, physical preparedness and functional state of boys and girls - students of Polish higher educational establishments. Physical Education of Students, 2013, vol.1, pp. 54-61. doi:10.6084/m9.figshare. 156359

The electronic version of this article is the complete one and can be found online at: http://www.sportedu.org.ua/html/arhive-e.html

This is an Open Access article distributed under the terms of the Creative Commons Attribution License, which permits unrestricted use, distribution, and reproduction in any medium, provided the original work is properly cited (http://creativecommons.org/licenses/by/3.0/deed.en).

Received: 15.01 .2013

Published: 09.02.2013 